\title{
Effect of olive meal and supplemental enzymes on performance traits, blood biochemistry, humoral immunity response and caecal microbiota of broilers
}

\author{
S. Sateri ${ }^{1}$, A. Seidavi ${ }^{1}$, M. Bouyeh ${ }^{1}$, P. Neumann ${ }^{2}$, M. Kutzler ${ }^{2}$, V. Laudadio ${ }^{3}$, F. Loperfido ${ }^{3} \&$ \\ V. Tufarelli ${ }^{3 \#}$ \\ ${ }^{1}$ Department of Animal Science, Rasht Branch, Islamic Azad University, Rasht, Iran \\ ${ }^{2}$ Department of Animal and Rangeland Sciences, Oregon State University, Corvallis, OR, USA \\ ${ }^{3}$ Section of Veterinary Science and Animal Production, Department of DETO, University of Bari 'Aldo Moro', Valenzano, \\ Bari, Italy
}

(Received 11 August 2017; Accepted 30 August 2017; First published online 29 September 2017)

\begin{abstract}
Copyright resides with the authors in terms of the Creative Commons Attribution 4.0 South African License.
See: http://creativecommons.org/licenses/by/4.0/za

Condition of use: The user may copy, distribute, transmit and adapt the work, but must recognize the authors and the South African Journal of Animal Science.
\end{abstract}

\begin{abstract}
This study investigated the growth performance, carcass characteristics, blood biochemistry, humoral immunity and caecal microbiota of broiler chicks fed $0,2,4,6$, and $8 \%$ olive meal $(\mathrm{OM})$ in diet. In addition, this study investigated the use of enzymatic feed supplements ( $\beta$-glucanase, phytase and hemicellulase) to enhance digestibility of high fibre diets. At the end of the feeding period (42 days), there were no significant differences among dietary groups on broiler growth performance, including bodyweight (BW) and bodyweight gain (BWG), feed intake (FI), and feed conversion efficiency (FCE). The evaluated carcass traits and meat cuts (breast, drumsticks and wings) did not vary among dietary treatments. Although some minor differences were observed in blood albumin and cholesterol concentrations among groups, the cecum microbiota did not differ in broilers. Antibody titers following vaccinations against infectious bronchitis virus (IBV) and Gumboro disease were higher in birds fed 4\% OM. Adding supplemental enzymes to diet had minimal effect on the parameters. Findings from this study support the literature, which suggests that $\mathrm{OM}$ is a suitable feed byproduct in broiler diets. Moreover, including OM in poultry rations has the potential to provide an economic and environmentally friendly alternative to traditional diets. Finally, the current trial identified that the addition of enzymes was not necessary to achieve optimal productive performance in broiler fed diet containing OM.
\end{abstract}

Keywords: Feed by-product, growth, nutrition, poultry

\#Corresponding author: vincenzo.tufarelli@uniba.it

\section{Introduction}

Using food by-products in livestock feeding is common practice for producers to reduce feed costs (Laudadio \& Tufarelli, 2011). The OM is a by-product of the olive oil mill extraction process. It is rich in lipids ( $73 \%$ oleic acid, $13 \%$ palmitic acid, and $7 \%$ linoleic acid), making it an economic ingredient for the livestock industry (Ranalli et al., 2002; Tufarelli et al., 2013). The fatty acid composition of poultry diet is highly effective not only in successful broiler chicken rearing, but also in the lipid composition of meat (Wood et al., 2008; Cherian, 2011).

Research on the effects of feeding OM in broiler diet is limited. However, studies investigating the use of OM in poultry diets may provide an opportunity to increase its popularity (Zarei et al., 2011; Zhang et al., 2013; Cayan \& Erener, 2015). A preliminary study using OM as a feedstuff for broiler chickens reported that feeding diets containing up to $9 \% \mathrm{OM}$ had no negative effect on growth performance and significantly increased the daily fibre intake in birds (Zangeneh \& Torki, 2011). Because OM is the remnant of the plant after the oil has been extracted, this by-product is high in non-digestible fibre. This fibre fraction is characterized by $\beta-1-4$ bonds, which are not well digested by monogastric species (Tufarelli et al., 2007; Zarei et al., 2011). When high fibre diets are used, feed producers can add supplemental enzymes such as $\beta$-glucanase, phytase or hemicellulase to the diet to increase fibre digestibility. Adding enzymes greatly increases the amount of nutrients that avian digestive tracts can obtain from these feed by-products (Campbell \& Bedford, 1992; Canoğullari et al., 1999; Adeola \& Cowieson, 2011; De Vries et al., 2012; O’Neill et al., 2014). 
Therefore, the objective of this study was to evaluate the effects of feeding broiler diets with various levels of OM with or without supplemental enzymes. The authors hypothesized that feeding a diet containing OM with supplemental enzymes might improve growth performance and carcass traits of broilers without affecting their blood biochemistry, humoral immunity response, and caecal microbiota.

\section{Material and Methods}

A 42-day experiment was conducted using one-day-old male Ross-308 broiler chicks according to the institutional ethical norms of the Faculty of Agriculture, Islamic Azad University (Rasht Branch, Iran). The poultry house was located in Karaj City, Iran. The mean temperature inside the experimental facility was maintained between 29 and $31^{\circ} \mathrm{C}$ from 1 to 7 days, 27 and $29^{\circ} \mathrm{C}$ from 8 to 14 days, and from 24 to $26{ }^{\circ} \mathrm{C}$ from 15 to 42 days of the rearing period. Relative humidity was maintained at $55-65 \%$. Broilers were reared under 20 hours of light per day in $1.2 \times 1.5 \mathrm{~m}$ cages. Rearing conditions were similar to all treatments. Broilers were allowed free access to fresh water and fed ad libitum. BW, BWG, and FI were determined weekly. Broilers were routinely vaccinated against endemic avian diseases in Iran. To reduce their stress in the 24-hour period after each vaccination, a multi-vitamin + electrolytes solution was added to their drinking water at a dilution of $1: 1000$.

Chicks $(n=300)$ were randomly assigned to ten dietary treatments, which varied in concentration of OM $(0,2,4,6$, and $8 \%$, respectively) and the addition of an enzyme supplement. The OM was purchased from a local company. Aflatoxin analysis of OM was below the normal level, revealing up to $2.86 \mathrm{ppb}$ of aflatoxin B and up to $3.27 \mathrm{ppb}$ of total aflatoxin. Broiler nutritional requirements were based on Ross-308 nutrition specifications (SVIAGEN, Scotland, UK). All diets under the two rearing periods were formulated to have the same energy and protein levels. The composition of diets is reported in Table 1. The enzyme supplement Natuzyme $P 50^{\circledR}$ was added to half of the tested diets. This supplement contained phytase $(100,000 \mathrm{U} / \mathrm{g}), \beta$ glucanase $(700 \mathrm{U} / \mathrm{g}), \alpha$-amylase $(700 \mathrm{U} / \mathrm{g})$, cellulase $(6,000 \mathrm{U} / \mathrm{g})$, pectinase $(700 \mathrm{U} / \mathrm{g})$, xylanase $(10,000 \mathrm{U} / \mathrm{g})$, lipase $(30 \mathrm{U} / \mathrm{g})$, and protease $(3,000 \mathrm{U} / \mathrm{g})$, as well as trace amounts of amyloglucosidase, hemicellulase, pentosonase, acid phytase, and acid phosphatase. There were ten birds per replicate and three replicates per treatment. Each replicate was considered an experimental unit.

Table 1 Ingredients and nutrient analysis of diets fed to broilers in starter and finisher periods

\begin{tabular}{|c|c|c|c|c|c|c|c|c|c|c|}
\hline \multirow[b]{2}{*}{ Ingredients (g/kg) } & \multicolumn{5}{|c|}{ Starter (1-21 days of age) } & \multicolumn{5}{|c|}{ Finisher (22-42 days of age) } \\
\hline & 0 & 2 & 4 & 6 & 8 & 0 & 2 & 4 & 6 & 8 \\
\hline Olive meal & - & 20.0 & 40.0 & 60.0 & 80.0 & - & 20.0 & 40.0 & 60.0 & 80.0 \\
\hline Corn & 500.3 & 486.1 & 471.9 & 456.4 & 439.8 & 572.5 & 566.0 & 557.6 & 550.7 & 542.2 \\
\hline Soybean meal & 370.0 & 370.0 & 370.0 & 370.0 & 369.6 & 302.6 & 307.2 & 313.0 & 316.0 & 320.6 \\
\hline Wheat & 50.0 & 50.0 & 50.0 & 50.0 & 50.0 & 55.1 & 47.0 & 39.0 & 34.0 & 28.0 \\
\hline Soybean oil & 40.1 & 37.2 & 34.3 & 31.5 & 29.5 & 40.0 & 48.0 & 56.6 & 63.5 & 71.4 \\
\hline Vitamin mixture $^{1}$ & 2.50 & 2.50 & 2.50 & 2.50 & 2.50 & 2.50 & 2.50 & 2.50 & 2.50 & 2.50 \\
\hline Mineral mxture ${ }^{2}$ & 2.50 & 2.50 & 2.50 & 2.50 & 2.50 & 2.50 & 2.50 & 2.50 & 2.50 & 2.50 \\
\hline Mineral oyster & 14.20 & 13.50 & 12.70 & 12.00 & 11.20 & 11.10 & 11.10 & 11.10 & 11.10 & 11.10 \\
\hline $\mathrm{Ca}_{\% 22} \mathrm{P}_{\% 18}$ & 12.60 & 12.50 & 12.50 & 12.50 & 12.40 & 10.70 & 10.70 & 10.70 & 10.70 & 10.70 \\
\hline $\mathrm{Ca}$ & 0.93 & 0.93 & 0.93 & 0.93 & 0.93 & 0.78 & 0.78 & 0.78 & 0.78 & 0.78 \\
\hline Available P & 0.38 & 0.38 & 0.38 & 0.38 & 0.38 & 0.37 & 0.37 & 0.36 & 0.36 & 0.35 \\
\hline $\mathrm{NaCl}$ & 4.40 & 2.9 & 1.30 & 1.00 & 1.00 & 2.00 & 2.00 & 2.00 & 2.00 & 2.00 \\
\hline LH-Chloride & 1.90 & 1.30 & 0.80 & 0.20 & 0.00 & 0.20 & 0.20 & 0.20 & 0.20 & 0.20 \\
\hline DL-Methionine & 1.50 & 1.50 & 1.50 & 1.50 & 1.50 & 0.80 & 0.80 & 0.80 & 0.80 & 0.80 \\
\hline Methionine & 0.49 & 0.49 & 0.49 & 0.49 & 0.49 & 0.43 & 0.43 & 0.43 & 0.43 & 0.42 \\
\hline Lysine & 1.14 & 1.16 & 1.20 & 1.23 & 1.28 & 1.04 & 1.05 & 1.04 & 1.04 & 1.04 \\
\hline Met + Cys & 0.84 & 0.84 & 0.84 & 0.84 & - & - & - & - & - & - \\
\hline $\mathrm{ME}, \mathrm{kcal} / \mathrm{kg}$ & 3000 & 3000 & 3000 & 3000 & 3000 & 3000 & 3000 & 3000 & 3000 & 3000 \\
\hline Crude protein, \% & 21.57 & 21.57 & 21.57 & 21.57 & 21.57 & 18.70 & 18.70 & 18.70 & 18.70 & 18.70 \\
\hline
\end{tabular}

'Vitamin A: $5000 \mathrm{IU} / \mathrm{g}$; vitamin D3: $500 \mathrm{IU} / \mathrm{g}$; vitamin E: $3 \mathrm{mg} / \mathrm{g}$; vitamin K3: $1.5 \mathrm{mg} / \mathrm{g}$; vitamin B2: $1 \mathrm{mg} / \mathrm{g}$;

${ }^{2}$ Calcium pantothenate: $4 \mathrm{mg} / \mathrm{g}$; niacin: $15 \mathrm{mg} / \mathrm{g}$; vitamin B6: $13 \mathrm{mg} / \mathrm{g}$; Cu: $3 \mathrm{mg} / \mathrm{g}$; Zn: $15 \mathrm{mg} / \mathrm{g}$; Mn: $20 \mathrm{mg} / \mathrm{g}$; Fe: 10 $\mathrm{mg} / \mathrm{g} ; \mathrm{K}: 0.3 \mathrm{mg} / \mathrm{g}$ 
Samples of blood $(5 \mathrm{ml})$ were collected from broilers' brachial vein into EDTA tubes at 16, 30, 33, 34 , 40 , and 42 days of age. Broilers were fasted for four hours prior to collection of blood on day 42 . Blood samples were centrifuged at $3000 \mathrm{rpm} \times 20 \mathrm{~min}$. Plasma was collected and stored at $-20^{\circ} \mathrm{C}$ until analysis. Humoral immune responses were measured from samples collected on days 16 and 34 for Newcastle disease virus (NDV), on day 30 for avian influenza (AI), and on day 40 for infectious bronchitis virus (IBV) and infectious bursal disease (Gumboro) (Pourhossein et al., 2015).

Antibody titers against NDV and Al were measured in birds using the haemagglutination inhibition test as described by Cunningham (1971). Antibody titers against IBV and Gumboro were measured with commercial ELISA kits (Bio-check BV, Gouda, Holland) in accordance with the manufacturer's instructions. The absorbance of ELISA controls and samples was read at $405 \mathrm{~nm}$ using a plate reader (Bio-Tek Instruments Inc. ELX 800; Winooski, VT, USA), as described by Pourhossein et al. (2015).

Total cholesterol, high density lipoprotein (HDL) cholesterol and low density lipoprotein (LDL) cholesterol, triglycerides, glucose, total protein, albumin, and uric acid were measured from samples collected at day 42. Briefly, total cholesterol, $\mathrm{HDL}$ and LDL cholesterol, and triglyceride concentrations were determined by enzymatic CHOD-PAP and COD-POD assays (Allain et al., 1974; Fossati \& Lorenzo, 1982). Glucose was measured by a glucose-oxidase photometric assay (Barham \& Trinder, 1972). Total protein was determined by the Biuret method (Gornall et al., 1949). Albumin was assessed based on the bromocresol green method (Doumas et al., 1971). Uric acid was determined by enzymatic methods using the uricase-TOOS method (Kayamori et al., 1997).

At the end of the feeding period (42 days), $20 \%$ of the broilers were slaughtered, and the weights of full and empty carcass, and defeathered BW were recorded, as well the weight and yield of meat cuts (breast, drumsticks and wings), abdominal fat, head, gizzard, heart, and neck.

Caecal microflora samples $(\sim 1 \mathrm{~g})$ were collected and transferred into sterile tubes with phosphatebuffered saline (PBS) $(9 \mathrm{ml})$ and shaken for approximately $30 \mathrm{~min}$. Serial dilutions $\left(10^{-2}, 10^{-3}, 10^{-4}, 10^{-5}\right.$, and $10^{-6}$, respectively) were made, and agarose plates were inoculated with $100 \mu \mathrm{l}$ of each dilution. Nutrient agar plates were incubated in aerobic conditions at $37^{\circ} \mathrm{C}$ for 48 hours to determine total aerobic bacteria counts. For isolation of Lactobacilli sp., dilutions were cultured in de Man Rogosa Sharpe agar (MRS agar) under anaerobic conditions at $37^{\circ} \mathrm{C}$ for 72 hours. Moreover, dilutions were cultured for coliforms in MacConkey agar in aerobic conditions for 24 hours. At the end of the incubation periods, the number of colony forming units (CFU) was counted for each dilution and media. Bacterial counts were reported as $\log _{10}$ of CFU per $1 \mathrm{~g}$ of caecal content (Abbasi et al., 2015).

All data were analysed by ANOVA using a $2 \times 5$ factorial arrangement with five OM levels $(0,2,4,6$, and $8 \%$, respectively) and two enzyme treatments ( 0 and $0.005 \%)$, using the two-way ANOVA procedure (SPSS, Chicago, IL, USA). Duncan's post hoc test was used if the initial test was significant at $P \leq 0.05$. The observations were considered statistically significant if $P \leq 0.05$.

\section{Results and Discussion}

The results of the present study are summarized in Tables 2-8. The addition of the supplemental enzymes to broiler diet had minimal impact on the evaluated parameters. In particular, there were no significant differences among dietary groups on growth performance in terms of final BW, average daily weight gain, FI and FE (Table 2). These results agree with a previous study by Rabayaa et al. (2001), that found no negative impact of OM in diet on broilers' performance traits.

At day 42 , the full and empty carcass weight, as well as the carcass yield, did not differ $(P>0.05)$ in broilers fed diets with added OM or supplemental dietary enzymes (Table 3 ). These results are in agreement with those of Omar (2005), who found that adding up to $10 \%$ of olive pulp in broiler diet had no significant effect on carcass characteristics. The same author also reported that the level of olive pulp in diet had no influence on the weight of edible (i.e. liver, heart, gizzard) or inedible (i.e. oesophagus, crop, proventriculus) organs. Moreover, as reported in Table 4, the weight and yield of breast, drumsticks and wings were not different $(P>0.05)$ when broilers were fed different levels of OM and enzyme or their combination.

Similar to the findings of Omar (2005), Sateri et al. (2014) and Al-Harthi (2017), the current study found that the yield of head, gizzard, heart, and neck, as well abdominal fat, did not differ $(P>0.05)$ in broilers fed various levels of OM with or without the addition of the enzyme supplement (Table 5). 
Table 2 Growth performance of broilers fed diets containing olive meal (OM) and enzyme or their interaction

\begin{tabular}{|c|c|c|c|c|c|}
\hline Item & & $\begin{array}{c}\text { BW } \\
\text { (g at } 42 \text { days) }\end{array}$ & $\begin{array}{l}\text { BW gain } \\
\text { (g/day) }\end{array}$ & $\begin{array}{l}\text { Feed intake } \\
\text { (g/day) }\end{array}$ & $\begin{array}{c}\text { Feed efficiency } \\
(\mathrm{g} / \mathrm{g})\end{array}$ \\
\hline \multirow{5}{*}{ Olive meal (\%) } & 0 & 2498.1 & 59.9 & 117.7 & $1.84^{\mathrm{ab}}$ \\
\hline & 2 & 2489.3 & 59.6 & 117.6 & $1.85^{\mathrm{a}}$ \\
\hline & 4 & 2515.3 & 60.3 & 117.9 & $1.82^{\mathrm{ab}}$ \\
\hline & 6 & 2520.1 & $60.4^{a}$ & 117.7 & $1.814^{\mathrm{b}}$ \\
\hline & 8 & 2497.6 & 59.8 & 117.9 & $1.84^{\mathrm{ab}}$ \\
\hline SEM & & 11.67 & 0.27 & 0.57 & 0.01 \\
\hline \multirow{2}{*}{ Enzyme } & - & 2509.6 & 60.1 & 118.0 & 1.83 \\
\hline & + & 2483.5 & 59.9 & 118.1 & 1.83 \\
\hline SEM & & 7.38 & 0.17 & 0.36 & 0.01 \\
\hline$\overline{O M}(0)-E(-)$ & & $2516.0^{\mathrm{ab}}$ & $60.3^{\mathrm{ab}}$ & 118.0 & $1.81^{\mathrm{a}}$ \\
\hline $\mathrm{OM}(0)-\mathrm{E}(+)$ & & $2480.3^{a b}$ & $59.5^{\mathrm{ab}}$ & 117.5 & $1.86^{\mathrm{ab}}$ \\
\hline $\mathrm{OM}(2)-\mathrm{E}(-)$ & & $2511.6^{\mathrm{ab}}$ & $60.2^{\mathrm{ab}}$ & 118.4 & $1.84^{\mathrm{ab}}$ \\
\hline $\mathrm{OM}(2)-\mathrm{E}(+)$ & & $2467.0^{b}$ & $59.2^{\mathrm{b}}$ & 116.8 & $1.86^{\mathrm{ab}}$ \\
\hline OM (4) - E (-) & & $2503.5^{\mathrm{ab}}$ & $60.0^{\mathrm{ab}}$ & 117.7 & $1.83^{\mathrm{ab}}$ \\
\hline $\mathrm{OM}(4)-\mathrm{E}(+)$ & & $2527.1^{\mathrm{a}}$ & $60.6^{a}$ & 118.1 & $1.81^{\mathrm{b}}$ \\
\hline $\mathrm{OM}(6)-\mathrm{E}(-)$ & & $2534.9^{a}$ & $60.8^{a}$ & 118.2 & $1.81^{\mathrm{b}}$ \\
\hline $\mathrm{OM}(6)-\mathrm{E}(+)$ & & $2505.3^{a b}$ & $60.1^{\mathrm{ab}}$ & 117.3 & $1.81^{\mathrm{b}}$ \\
\hline $\mathrm{OM}(8)-\mathrm{E}(-)$ & & $2482.2^{\mathrm{ab}}$ & $59.6^{\mathrm{ab}}$ & 117.7 & $1.85^{\mathrm{ab}}$ \\
\hline $\mathrm{OM}(8)-\mathrm{E}(+)$ & & $2513.0^{\mathrm{ab}}$ & $60.3^{\mathrm{ab}}$ & 118.0 & $1.83^{\mathrm{ab}}$ \\
\hline SEM & & 16.50 & 0.39 & 0.61 & 0.02 \\
\hline
\end{tabular}

BW: bodyweight; ${ }^{a, b}$ means within each column of dietary treatments with no common superscript differ significantly at $P<$ 0.05

At day 42 , circulating total cholesterol was higher $(P<0.05)$ in broilers fed the diet containing $2 \%$ OM without the supplemental enzyme compared with those fed $4 \%$ OM and the enzyme (Table 6 ).

However, there were no differences $(P>0.05)$ among treatment groups for blood LDL and HDLcholesterol, triglycerides, total protein, albumin, glucose and uric acid. These results agreed with similar studies that examined the changes in blood biochemistry parameters in laying hens fed diets with varying concentrations of olive pulp with or without $\beta$-mannanase enzyme supplementation (Zangeneh \& Torki, 2011; Sayehban, 2015; Sayehban, 2016).

NDV antibody titers did not differ $(P>0.05)$ in any of the groups after either of the vaccinations (Table 7 ), or for Al antibody titers. However, IB antibody titer was significantly $(P<0.05)$ higher in birds fed $2 \%$ and $4 \%$ OM in diet with supplemental enzymes, compared with that containing 6\% OM with supplemental enzyme and the control group (without OM or supplemental enzymes). In addition, IBD (Gumboro) antibody titers were highest $(P<0.05)$ in birds fed $4 \%$ OM diet including the enzyme supplement compared with broilers fed $6 \%$ and $8 \%$ OM without enzyme supplement.

This is the first study to examine the effects of OM addition to broiler diet on caecal microbiota (Table 8). Extensive research is available on the effects of diet on the biodiversity of the caecal microbiota in broiler chickens. In healthy chickens, the caecal microbiota plays an important role in nutrient assimilation and in the prevention of pathogenic bacteria colonization (Apajalahti, 2005). This is important because these pathogens can spread to humans through the consumption of meat that has been contaminated during slaughter. In poultry, in addition, prophylactic antibiotics are widely used to improve growth performance (Allen \& Stanton, 2014), but this practice can result in the development of a reservoir of antibiotic resistant bacteria, which can affect public health (Zhou et al., 2012).

Previous studies have focused on the addition of supplemental enzymes, yeast and other probiotics and, depending on the study, some beneficial effects were found (Dhama et al., 2015; Rezaei et al., 2015; Alefzadeh et al., 2016). In the current study, the numbers of aerobic, lactic acid-producing, and coliform bacteria did not differ $(P>0.05)$ among experimental groups, demonstrating the safety of adding $\mathrm{OM}$ to both animal and human populations. 
Table 3 Carcass traits at 42 nd day of age in broilers fed diets containing olive meal (OM) and enzyme or their interaction

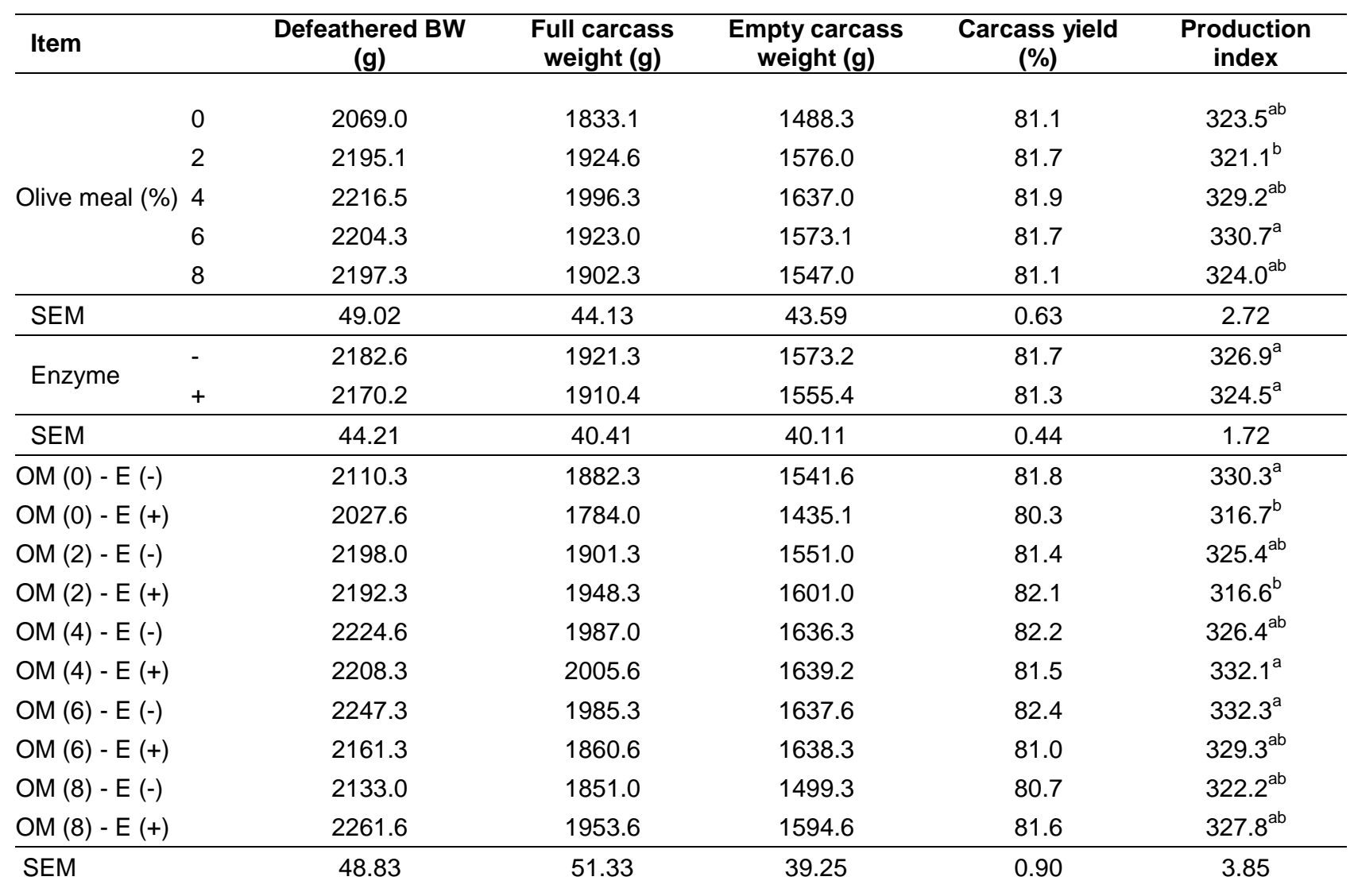

${ }^{\bar{a}, \mathrm{~b}}$ Means within each column of dietary treatments with no common superscript differ significantly at $P<0.05$

Table 4 Meat cuts at 42nd days of age of broilers fed diets containing olive meal (OM) and enzyme or their interaction

\begin{tabular}{|c|c|c|c|c|c|c|c|}
\hline Item & & $\begin{array}{c}\text { Breast } \\
\text { weight } \\
(\mathrm{g})\end{array}$ & $\begin{array}{c}\text { Breast } \\
\text { yield } \\
(\%)\end{array}$ & $\begin{array}{c}\text { Drumsticks } \\
\text { weight } \\
\text { (g) }\end{array}$ & $\begin{array}{c}\text { Drumsticks } \\
\text { yield } \\
(\%)\end{array}$ & $\begin{array}{l}\text { Wings } \\
\text { weight } \\
(g)\end{array}$ & $\begin{array}{c}\text { Wings } \\
\text { yield } \\
(\%) \\
\end{array}$ \\
\hline \multirow{5}{*}{ Olive meal (\%) } & 0 & 629.1 & 30.29 & 566.6 & 27.35 & 174.2 & 8.49 \\
\hline & 2 & 675.7 & 30.67 & 605.1 & 27.52 & 173.8 & 7.95 \\
\hline & 4 & 704.0 & 31.66 & 633.2 & 28.49 & 181.3 & 8.22 \\
\hline & 6 & 677.7 & 30.69 & 607.7 & 27.58 & 172.9 & 7.86 \\
\hline & 8 & 675.8 & 30.66 & 589.8 & 26.76 & 171.6 & 7.85 \\
\hline SEM & & 37.29 & 0.882 & 27.33 & 0.555 & 9.04 & 0.332 \\
\hline \multirow{2}{*}{ Enzyme } & - & 680.3 & 31.06 & 600.4 & 27.45 & 174.1 & 8.02 \\
\hline & + & 664.6 & 30.53 & 600.5 & 27.63 & 174.4 & 8.13 \\
\hline SEM & & 23.58 & 0.558 & 17.28 & 0.351 & 8.37 & 0.210 \\
\hline
\end{tabular}


Table 5 Carcass traits at 42 nd day of age of broilers fed diets containing various levels of olive meal (OM) and enzyme or their interaction

\begin{tabular}{|c|c|c|c|c|c|c|}
\hline Item & & Abdominal fat (\%) & Head (\%) & Gizzard (\%) & Heart (\%) & Neck (\%) \\
\hline \multirow{5}{*}{ Olive meal (\%) } & 0 & 1.74 & 2.45 & 2.85 & 0.59 & 2.80 \\
\hline & 2 & 1.61 & 2.32 & 2.80 & 0.59 & 2.66 \\
\hline & 4 & 1.63 & 2.36 & 2.81 & 0.61 & 2.69 \\
\hline & 6 & 1.59 & 2.32 & 2.61 & 0.60 & 2.66 \\
\hline & 8 & 1.60 & 2.31 & 2.73 & 0.60 & 2.64 \\
\hline SEM & & 0.078 & 0.070 & 0.148 & 0.023 & 0.104 \\
\hline \multirow{2}{*}{ Enzyme in diet } & - & 1.61 & 2.33 & 2.72 & 0.59 & 2.66 \\
\hline & + & 1.61 & 2.38 & 2.80 & 0.61 & 2.72 \\
\hline SEM & & 0.049 & 0.044 & 0.093 & 0.015 & 0.06 \\
\hline
\end{tabular}

Table 6 Effect of diets containing olive meal $(\mathrm{OM})$ and enzyme or their interaction on blood parameters of broiler chickens

\begin{tabular}{|c|c|c|c|c|c|c|c|c|c|c|}
\hline \multicolumn{2}{|l|}{ Item } & $\begin{array}{c}\text { Total } \\
\text { protein } \\
\text { (g/dl) }\end{array}$ & $\begin{array}{c}\text { Albumin } \\
(\mathrm{g} / \mathrm{dl})\end{array}$ & $\begin{array}{l}\text { Glucose } \\
\text { (mg/dl) }\end{array}$ & $\begin{array}{l}\text { Uric acid } \\
\text { (mg/dl) }\end{array}$ & $\begin{array}{c}\text { Cholesterol } \\
(\mathrm{mg} / \mathrm{dl})\end{array}$ & $\begin{array}{l}\text { Triglycerides } \\
\text { (mg/dl) }\end{array}$ & $\begin{array}{c}\text { LDL } \\
(\mathrm{mg} / \mathrm{dl})\end{array}$ & $\begin{array}{c}\mathrm{HDL} \\
(\mathrm{mg} / \mathrm{dl})\end{array}$ & $\begin{array}{l}\text { LDL/ } \\
\text { HDL }\end{array}$ \\
\hline \multirow{5}{*}{$\begin{array}{l}\text { Olive meal } \\
(\%)\end{array}$} & 0 & 3.25 & $1.51^{\mathrm{b}}$ & 228.3 & 4.78 & 156.6 & 100.8 & 62.0 & 71.6 & 0.84 \\
\hline & 2 & 2.90 & $2.08^{\mathrm{a}}$ & 227.1 & 4.85 & 170.0 & 119.0 & 69.1 & 77.8 & 0.87 \\
\hline & 4 & 3.19 & $1.88^{\mathrm{ab}}$ & 231.5 & 4.46 & 155.1 & 94.8 & 59.1 & 77.0 & 0.77 \\
\hline & 6 & 3.45 & $2.01^{\mathrm{ab}}$ & 216.1 & 4.45 & 161.0 & 101.5 & 64.5 & 78.0 & 0.82 \\
\hline & 8 & 3.43 & $1.95^{\mathrm{ab}}$ & 226.0 & 5.51 & 170.8 & 94.5 & 75.3 & 76.5 & 0.98 \\
\hline SEM & & 0.26 & 0.17 & 6.23 & 0.41 & 6.56 & 12.23 & 5.72 & 3.49 & 0.09 \\
\hline \multirow{2}{*}{ Enzyme } & - & 3.22 & 1.74 & 226.0 & 4.85 & 165.8 & 108.7 & 68.4 & 76.0 & 0.89 \\
\hline & + & 3.27 & 2.04 & 225.6 & 5.17 & 159.7 & 99.5 & 63.6 & 76.3 & 0.82 \\
\hline SEM & & 0.16 & 0.10 & 3.94 & 0.26 & 4.15 & 7.74 & 3.59 & 2.21 & 0.06 \\
\hline \multicolumn{2}{|c|}{$\overline{O M}(0)-E(-)$} & 3.01 & 1.50 & 229.3 & 5.06 & $151.6^{\mathrm{ab}}$ & 124.6 & 54.6 & 70.3 & 0.76 \\
\hline \multicolumn{2}{|c|}{$\mathrm{OM}(0)-\mathrm{E}(+)$} & 3.50 & 1.53 & 227.3 & 4.50 & $161.6^{\mathrm{ab}}$ & 97.0 & 69.3 & 73.0 & 0.91 \\
\hline \multicolumn{2}{|c|}{ OM (2) - E (-) } & 2.95 & 1.90 & 224.6 & 4.36 & $179.3^{\mathrm{a}}$ & 111.0 & 75.0 & 83.3 & 0.87 \\
\hline \multicolumn{2}{|c|}{ OM (2) - E (+) } & 2.86 & 2.27 & 229.6 & 5.33 & $160.6^{\mathrm{ab}}$ & 127.0 & 63.3 & 72.3 & 0.88 \\
\hline \multicolumn{2}{|c|}{ OM (4) - E (-) } & 3.43 & 1.63 & 236.3 & 5.50 & $164.6^{\mathrm{ab}}$ & 114.6 & 67.3 & 74.3 & 0.90 \\
\hline \multicolumn{2}{|c|}{ OM (4) - E (+) } & 2.96 & 2.13 & 226.6 & 5.43 & $145.7^{\mathrm{b}}$ & 75.0 & 51.0 & 79.6 & 0.64 \\
\hline \multicolumn{2}{|c|}{ OM (6) - E (-) } & 3.10 & 1.83 & 219.3 & 4.23 & $166.6^{\mathrm{ab}}$ & 95.3 & 72.0 & 79.0 & 0.92 \\
\hline \multicolumn{2}{|c|}{ OM (6) - E (+) } & 3.79 & 2.20 & 213.0 & 4.66 & $155.3^{\mathrm{ab}}$ & 107.6 & 57.0 & 77.0 & 0.72 \\
\hline \multicolumn{2}{|c|}{ OM (8) - E (-) } & 3.62 & 1.83 & 220.6 & 5.10 & $166.3^{\mathrm{ab}}$ & 98.0 & 73.3 & 73.3 & 1.01 \\
\hline \multicolumn{2}{|c|}{ OM (8) - E (+) } & 3.24 & 2.06 & 231.3 & 5.93 & $175.3^{\mathrm{ab}}$ & 91.0 & 77.3 & 79.6 & 0.96 \\
\hline \multicolumn{2}{|c|}{ SEM } & 0.37 & 0.23 & 8.81 & 0.58 & 9.27 & 17.30 & 8.02 & 4.93 & 0.13 \\
\hline
\end{tabular}


Table 7 Immune response $\left(\log _{10}\right)$ after vaccination of broilers fed diets containing various levels of olive meal $(\mathrm{OM})$ with and without enzyme or their interaction

\begin{tabular}{|c|c|c|c|c|c|c|}
\hline Item & & $\begin{array}{l}\text { Antibody titer } \\
\text { against Avian } \\
\text { Influenza }\end{array}$ & $\begin{array}{l}\text { Antibody titer } \\
\text { against 1st } \\
\text { injection of } \\
\text { Newcastle }\end{array}$ & $\begin{array}{l}\text { Antibody titer } \\
\text { against 2nd } \\
\text { injection of } \\
\text { Newcastle }\end{array}$ & $\begin{array}{l}\text { Antibody titer } \\
\text { against } \\
\text { Infectious } \\
\text { Bronchitis } \\
\text { virus }\end{array}$ & $\begin{array}{l}\text { Antibody titer } \\
\text { against } \\
\text { Gumboro virus }\end{array}$ \\
\hline \multirow{5}{*}{ Olive meal (\%) } & 0 & 3.00 & 3.33 & 3.00 & 4.22 & 6.06 \\
\hline & 2 & 2.83 & 3.50 & 3.00 & 6.21 & 5.72 \\
\hline & 4 & 2.67 & 3.50 & 3.50 & 5.99 & 6.87 \\
\hline & 6 & 3.00 & 3.50 & 3.50 & 4.42 & 5.76 \\
\hline & 8 & 2.67 & 3.50 & 3.83 & 4.84 & 5.53 \\
\hline SEM & & 0.316 & 0.298 & 0.365 & 0.492 & 0.431 \\
\hline \multirow{2}{*}{ Enzyme } & - & 2.93 & 3.53 & 3.60 & 4.79 & 5.81 \\
\hline & + & 2.73 & 3.40 & 3.13 & 5.48 & 6.14 \\
\hline SEM & & 0.200 & 0.189 & 0.231 & 0.311 & 0.273 \\
\hline $\mathrm{OM}(0)-\mathrm{E}(-)$ & & 3.00 & 3.33 & 3.33 & $3.78^{b}$ & $6.22^{\mathrm{ab}}$ \\
\hline OM (0) - E (+) & & 3.00 & 3.33 & 2.67 & $5.07^{\mathrm{ab}}$ & $5.91^{\mathrm{ab}}$ \\
\hline OM (2) - E (-) & & 2.66 & 3.66 & 3.00 & $5.20^{\mathrm{ab}}$ & $6.12^{\mathrm{ab}}$ \\
\hline OM (2) - E (+) & & 3.00 & 3.33 & 3.00 & $6.82^{\mathrm{a}}$ & $5.33^{\mathrm{b}}$ \\
\hline OM (4) - E (-) & & 3.00 & 3.33 & 4.33 & $5.20^{a b}$ & $6.18^{\mathrm{ab}}$ \\
\hline OM (4) - E (+) & & 2.33 & 3.66 & 2.67 & $6.78^{a}$ & $7.48^{\mathrm{a}}$ \\
\hline OM (6) - E (-) & & 3.33 & 3.67 & 4.00 & $4.73^{\mathrm{ab}}$ & $5.32^{\mathrm{b}}$ \\
\hline OM (6) - E (+) & & 2.66 & 3.33 & 3.00 & $4.09^{b}$ & $6.21^{\mathrm{ab}}$ \\
\hline OM (8) - E (-) & & 2.67 & 3.66 & 3.33 & $5.05^{\mathrm{ab}}$ & $5.26^{\mathrm{b}}$ \\
\hline OM (8) - E (+) & & 2.66 & 3.33 & 4.33 & $4.64^{\mathrm{ab}}$ & $5.81^{\mathrm{ab}}$ \\
\hline SEM & & 0.477 & 0.422 & 0.516 & 0.692 & 0.610 \\
\hline
\end{tabular}

Means within each column of dietary treatments with no common superscript differ significantly at $P<0.05$

Table 8 Microflora of cecum ( $\log _{10} \mathrm{CFU}$ ) at 42nd day of age of broilers fed diets containing various levels of olive meal (OM) and enzyme or their interaction

\begin{tabular}{lcccccc}
\hline Item & & $\begin{array}{c}\text { Aerobic } \\
\text { bacteria total }\end{array}$ & $\begin{array}{c}\text { Lactic acid- } \\
\text { producing } \\
\text { bacteria }\end{array}$ & $\begin{array}{c}\text { Coliforms } \\
\text { bacteria }\end{array}$ & $\begin{array}{c}\text { Lactobacillus } \\
\text { bacteria }\end{array}$ & E. coli \\
\hline & 0 & 8.46 & 7.76 & 8.15 & 7.75 & 7.74 \\
& 2 & 8.37 & 7.55 & 7.89 & 7.13 & 7.37 \\
Olive meal (OM) (\%) & 4 & 8.46 & 7.66 & 8.16 & 7.31 & 7.55 \\
& 6 & 7.79 & 7.18 & 7.48 & 6.81 & 7.07 \\
& 8 & 7.88 & 7.22 & 7.55 & 7.08 & 6.88 \\
\hline SEM & & 0.531 & 0.509 & 0.487 & 0.488 & 0.502 \\
\hline \multirow{2}{*}{ Enzyme } & - & 8.17 & 7.70 & 7.87 & 7.24 & 7.25 \\
& + & 8.22 & 7.24 & 7.83 & 7.19 & 7.40 \\
\hline SEM & & 0.336 & 0.322 & 0.308 & 0.283 & 0.317 \\
\hline
\end{tabular}

\section{Conclusion}

In conclusion, a broiler diet containing 4\% OM with the addition of an enzyme supplement resulted in an appropriate combination to support broiler growth performance and carcass characteristics without 
negatively affecting blood biochemistry, humoral immunity response, and caecal microbiota. The findings in this study support the literature, which suggests $\mathrm{OM}$ as a suitable ingredient for commercial broiler diets. Moreover, adding OM by-products to poultry diet could provide an economic and environmentally friendly alternative to traditional diets. Thus, this study identified that the inclusion of dietary enzyme supplements is not necessary to achieve optimal productive performance of birds fed a diet containing $8 \%$ (or less) OM.

\section{Acknowledgments}

Financial support by Rasht Branch, Islamic Azad University, Grant number 4.5830 is gratefully acknowledged. The authors are grateful to Islamic Azad University, Rasht Branch, Rasht, Iran for support.

\section{Authors' Contributions}

All the authors contributed and commented on early and final version of manuscript.

\section{Conflict of Interest Declaration}

The authors have no conflict of interest to declare.

\section{References}

Abbasi, H., Seidavi, A., Liu, W. \& Asadpour, L., 2015. Investigation on the effect of different levels of dried sweet orange (Citrus sinensis) pulp on performance, carcass characteristics and physiological and biochemical parameters in broiler chicken. Saudi J. Biol. Sci. 22, 139-146.

Adeola, O. \& Cowieson, A.J., 2011. Board-invited review: Opportunities and challenges in using exogenous enzymes to improve nonruminant animal production. J. Anim. Sci. 89, 3189-3218.

Alefzadeh, T., Bouyeh, M., den Hoven, R.V., Seidavi, A., Laudadio, V., \& Tufarelli, V., 2016. Effect of dietary dried orange (Citrus sinensis) peel powder and exogenous multi-enzymes on growth and carcass traits and ileal microflora of broiler chickens. Pak. J. Zool. 48, 1891-1897.

Al-Harthi, M.A., 2017. The effect of olive cake, with or without enzymes supplementation, on growth performance, carcass characteristics, lymphoid organs and lipid metabolism of broiler chickens. Rev. Bras. Ciên. Avíc. 19, 8390.

Allain, C.C., Poon, L.S., Chan, C.S.G., Richmond, W. \& Fu, P.C., 1974. Enzymatic determination of total serum cholesterol. Clin. Chem. 20, 470-475.

Allen, H.K. \& Stanton, T.B., 2014. Altered egos: Antibiotic effects on food animal microbiomes. Ann. Rev. Microbiol. 68, 297-31.

Apajalahti, J., 2005. Comparative gut microflora, metabolic challenges, and potential opportunities. J. Appl. Poult. Res. 14, 444-453.

Barham, D. \& Trinder, P., 1972. An improved color reagent for the determination of blood glucose by the oxidase system. The Analyst 97, 142-145.

Campbell, G.L. \& Bedford M.R., 1992. Enzyme applications for monogastric feeds: A review. Can. J. Anim. Sci. 72, 449466.

Canoğullari, S., Okan, F. \& Ayaşan, T., 1999. The effects of alfa amylase and protease supplementation to broiler diets on performance and carcass characteristics. VIV Poultry YUTAV'99, Istanbul. Y Bildiriler Kitabi, pp. 505-514.

Cayan, H., \& Erener, G., 2015. Effect of olive leaf (Olea europaea) powder on laying hens performance, egg quality and egg yolk cholesterol levels. Asian Austral J. Anim. Sci. 28(4), 538-543.

Cherian, G., 2011. Essential fatty acids and early life programming in meat-type birds. World Poult. Sci. J. 67, 599-614.

Cunningham C.H., 1971. Virologia Practica, 6th ed. Acribia, Zaragoza, Spain. p. 260.

De Vries, S., Pustjens, A.M., Schols, H.A., Hendriks, W.H. \& Gerrits, W.J.J., 2012. Improving digestive utilization of fibrerich feedstuffs in pigs and poultry by processing and enzyme technologies. Anim. Feed Sci. Technol. 178, 123138.

Dhama, K., Latheef, S.K., Mani, S., Samad, H.A., Karthik, K., Tiwari, R., Khan, R.U., Alagawany, M., Farag, M.R., Alam, G.M., Laudadio, V. \& Tufarelli, V., 2015. Multiple beneficial applications and modes of action of herbs in poultry health and production - A Review. Int. J. Pharmacol. 11, 152-176.

Doumas, B.T., Watson, W.A. \& Biggs, H.G., 1971. Albumin standards and the measurement of serum albumin with bromocresol green. Clin. Chim. Acta 31, 87-96.

Fossati, P. \& Lorenzo, P., 1982. Serum triglycerides determined colorimetrically with an enzyme that produces hydrogenperoxide. Clin. Chem. 28, 2077-2080.

Gornall, A.G., Bardawill, C.J. \& David, M.M., 1949. Determination of serum proteins by means of the biuret reaction. J. Biol. Chem. 177, 751-766.

Kayamori, Y., Katayama, Y. Matsuyama, T. \& Urata, T., 1997. Enzymatic method for assaying uric acid in serum with a new tetrazolium salt produces water-soluble formazan dye. Clin. Biochem. 30, 595-599.

Laudadio, V., \& Tufarelli, V., 2011. Dehulled-micronised lupin (Lupinus albus L. cv. Multitalia) as the main protein source for broilers: influence on growth performance, carcass traits and meat fatty acid composition. J. Sci. Food Agric. 91, 2081-2087.

O’Neill H.M., Smith, J.A. \& Bedford, M.R., 2014. Multicarbohydrase enzymes for non-ruminants. Asian Austral. J. Anim. Sci. 27, 290-295.

Omar, J.M.A., 2005. Carcass composition and visceral organ mass of broiler chicks fed different levels of olive pulp. IUG J. Nat. Stud. 13, 175-184. 
Pourhossein, Z., Qotbi, A.A.A., Seidavi, A.R., Laudadio, V., Centoducati, G. \& Tufarelli V., 2015. Effect of different levels of dietary sweet orange (Citrus sinensis) peel extract on humoral immune system responses in broiler chickens. Anim. Sci. J. 86, 105-110.

Rabayaa, E., Omar, J.A. \& Othman, R.A., 2001. Utilization of olive pulp in broiler rations. An-Najah Univ. J. Res. 15, 133144.

Ranalli, A., Pollastri, L., Contendo, S., Di Loreto, G., lannucci, E., Lucera, L. \& Russi F., 2002. Acylglycerol ad fatty acid composition of pulp, seed and whole olive fruit oils: Their use to characterize fruit variety by chemometrics. J. Agric. Food Chem. 50, 3775-3779.

Rezaei, S., Faseleh Jahromi, M., Liang, J.B., Zulkifli, I., Farjam, A.S., Laudadio, V., \& Tufarelli, V., 2015. Effect of oligosaccharides extract from palm kernel expeller on growth performance, gut microbiota and immune response in broiler chickens. Poult. Sci. 94, 2414-2420.

Sateri, S., Seidavi, A. \& Bouyeh, M., 2014. Effects of olive pulp and multi enzyme on thymus, liver, spleen and bursa of fabricius of broiler chickens. Int. J. Biosc. 5(5), 66-71.

Sayehban, P., Seidavi, A., Dadashbeiki, M., Ghorbani, A., Araújo, W.A.G. \& Albino, L.F.T., 2015. Effects of different dietary levels of two types of olive pulp and exogenous enzyme supplementation on the gastrointestinal tract size, ımmunology and hematology of broilers. Rev. Bras. Ciênc. Av. 17, 73-85.

Sayehban, P., Seidavi, A., Dadashbeiki, M., Ghorbani, A., Araújo, W.A.G. \& Albino, L.F.T., 2016. Effects of different levels of two types of olive pulp with or without exogenous enzyme supplementation on broiler performance and economic parameters. Rev. Bras. Ciênc. Av. 18, 489-500.

Tufarelli, V., Introna, M., Cazzato, E., Mazzei, D. \& Laudadio, V., 2013. Suitability of partly destoned exhausted olive cake as by-product feed ingredient for lamb production. J. Anim. Sci. 91, 872-877.

Wood, J.D., Enser, M., Fisher, A.V., Sheard, P.R., Richardson, R.I., Hughes, S.I. \& Whittington, F.M., 2008. Fat deposition, fatty acid composition, and meat quality: a review. Meat Sci. 78, 343-358.

Zangeneh, S. \& Torki, M., 2011. Effects of $\beta$-mannanase supplementing of olive pulp-included diet on performance of laying hens, egg quality characteristics, humoral and cellular immune response and blood parameters. Global Vet. 7, 391-398.

Zarei, M., Ehsani, M. \& Torki, M., 2011. Productive performance of laying hens fed wheat-based diets included olive pulp with or without a commercial enzyme product. Afr. J. Biotechnol. 10, 4304-4312.

Zhang, Z.F., Zhou, T.X. \& Kim, I.H., 2013. Effects of dietary olive oil on growth performance, carcass parameters, serum characteristics, and fatty acid composition of breast and drumstick meat in broilers. Asian Austral J Anim Sci. 26(3), 416-422.

Zhou, W., Wang, Y. \& Lin, J., 2012. Functional cloning and characterization of antibiotic resistance genes from the chicken gut microbiome. Appl. Environ. Microbiol. 78, 3028-3032. 